\title{
CITY OF MADNESS: SEBUAH POTRET ESAI FOTOGRAFI ORANG DENGAN MASALAH KEJIWAAN (ODMK) JALANAN
}

\author{
Daniar Wikan Setyanto \\ Program Studi Desain Komunikasi Visual, Fakultas Ilmu Komputer, \\ Universitas Dian Nuswantoro Semarang \\ daniarwikan@dsn.dinus.ac.id
}

\begin{abstract}
Abstrak
City Of Madness: Sebuah Potret Esai Fotografi Orang Dengan Masalah Kejiwaan (ODMK) Jalanan adalah sebuah upaya dalam memotret kehidupan ODMK khususnya yang terlantar di jalanan. Fotografi potret dalam City of Madness mencoba memberi penggambaran ikonik secara detail dari ODMK yang terlantar, gambaran tersebut mulai dari mimik wajah, bentuk tubuh, cara berpakaiaan, serta ciri-ciri fisik lainnya. Dalam rangkaian karya fotografi City of Madness, fotografer memotret orang gila yang ditemui di jalan-jalan kota Semarang Yogyakarta secara tidak terduga. Foto orang gila atau lebih tepatnya ikon orang gila dihadirkan kembali dalam sebuah frame foto jurnalistik potraiture. Foto tersebut secara tersirat merekam secara detail ciri-ciri visual yang ada dalam diri mereka.
\end{abstract}

Kata kunci : Fotografi Esai, Potret, Orang Gila Jalanan

\begin{abstract}
A Photographic Essay ODMK street is an effort in portraying the lives ODMK (People With Psychiatric Problems), particularly displaced in the streets. Portrait photography in the City of Madness try to give a detailed depiction of the iconic ODMK displaced, these images ranging from facial expressions, body shape, how to dress, as well as other physical characteristics. photographer portrays a madman who met in Semarang and Jogjakarta city streets. Photo madman or rather iconic madman reintroduced in a frame of photojournalism potraiture. The photos were implicitly recording visual icon of madmad.
\end{abstract}

Keyword : Photographic Essay, Potraiture, Madman 


\section{PENDAHULUAN}

Kehidupan manusia dewasa ini sangat kompleks dan semakin sulit, bertambahnya tekanan hidup (stressor psikososial) akibat budaya masyarakat modern yang semakin sekuler, menyebabkan manusia tidak dapat menghindari tekanan hidup. Kondisi ini membuat manusia modern rentan terhadap penyakit kejiwaan, penyebabnyapun bermacam-macam, mulai dari himpitan ekonomi, bencanan alam, tragedi, masalah keluarga, hingga putus cinta. Kondisi kritis ini tak pelak membawa dampak terhadap meningkatnya para penyandang sakit jiwa baik ringan maupun kritis. Semakin besar tekanan yang dihadapi semakin besar pula kans manusia tersebut terjangkit penyakit kejiwaan.

Hal di atas dapat menyebabkan meningkatnya penderita masalah kejiwaan di Indonesia, padahal Rumah Sakit Jiwa (RSJ) merupakan fasilitas utama untuk menangani masalah gangguan kejiwaan di Indonesia belum cukup memadai untuk dapat menampung semua penderita gangguan jiwa yang ada. Kenyataan di masyarakat, masih banyak ditemukan Orang Dengan Masalah Kejiwaan (ODMK) yang dipasung, diabaikan, terlantar bahkan menggelandang. Hal ini karena Rumah Sakit Jiwa di Indonesia belum mampu menampung semua ODMK yang ada. Jumlah warga Jawa Tengah yang mengidap gangguan jiwa dari tahun ke tahun terus meningkat. "Pada 2015, jumlah penderita bertambah menjadi 317.504 jiwa," mengutip data dari Dinas Kesehatan Jawa Tengah yang menyebut jumlah gangguan jiwa pada 2013 masih 121.962 penderita. Sedangkan pada 2014 meningkat menjadi 260.247 orang.

Penelitian ini tidak membahas mengenai permasalahan ODMK secara medis, namun justru mencoba menangkap fenomena tersebut dari sudut pandang seni foto. Secara khusus ODMK yang terlantar sebagai obyek fotografis. Fotografi sendiri merupakan sebuah cabang seni visual yang banyak digunakan di era modern, sebagai contoh iklan, berita, cover buku/majalah, dan lain-lain selalu menggunakan fotografi sebagai ilustrasi. Fotografi dianggap sebagai media yang dapat memperlihatkan gambaran seutuhnya dari detail obyek yang difoto, lain halnya dengan ilustrasi/gambar yang memiliki tingkat distorsi dalam penyampaiaan ikon. Fotografi justru merekam gambar persis sama seperti aslinya. Foto-foto dalam City of Madness, merupakan foto jurnalistik potrait oleh karena itu objek yang terekam adalah obyek yg riil, tanpa rekayasa apapun.

City of Madness adalah sebuah upaya dalam memotret kehidupan ODMK khususnya yang terlantar di jalanan. Fotografi potrait dalam City of Madness mencoba memberi penggambaran ikonik secara detail dari ODMK yang terlantar, gambaran tersebut mulai dari mimik wajah, bentuk tubuh, cara berpakaiaan, serta ciri-ciri fisik lainnya. Namun supaya lebih dalam maka penulis juga akan menggali karya-karya dalam City of Madness, dengan menggunakan pendekatan semiotika atau ilmu tentang tanda. Karena semiotika dianggap sebagai sebuah teori yang relevan untuk membedah subyek fotografi seperti yang dilakukan Roland Barthes dalam bukunya Camera Lucida. 


\section{TINJAUAN TEORI}

\subsection{Fotografi Esai}

Potret esai fotografi secara garis besar merupakan penggabungan dari dua jenis fotografi yaitu fotografi potrait (potraiture) dan fotografi esai (essay photo). Secara umum fotografi potrait adalah jenis fotografi yang berfokus pada karakter wajah atau potret seseorang. Namun dalam perkembangannya fotografi potrait tidak hanya sekedar memotret wajah saja namun tubuh secara keseluruhan. Meski demikian ciri dari fotografi potret adalah merekam karakter/kekhasan dari sosok orang/tokoh yang ada dalam bingkai. Sedangkan Esai foto merupakan teknik fotografi untuk menyampaikan pendapat atau opini secara sekaligus, fakta dan peristiwa hanyalah pelengkapnya. la menganalisa dari pada melaporkan suatu gejala, peristiwa atau isue tertentu. la adalah rangkaian argumen yang menyatakan sudut pandang tertentu dari si fotografer. Jadi apabila digabung maka genre Potret esai fotografi adalah sebuah genre fotografi jurnalistik yang bertujuan menyampaikan pendapat/opini serta menyampaikan pendapat mengenai gejala tertentu (dalam hal ini ODMK) dengan teknik pemotretan gaya potraiture.

\subsection{Ikon, Indeks dan Simbol sebagai Tinjauan Visual}

Selain memotret, fotografer juga mencoba untuk membahas hasil foto tersebut menggunakan pendekatan semiotika Pierce mengenai ikon, Indeks, dan simbol yang terdapat dalam foto tersebut. Dalam sebuah disiplin ilmu, Semiotika juga hadir dalam kajian fotografi. Karena fotografi sebagai bentuk representasi (ikon) akan subyek yang ter"beku"kan memiliki kekayaan akan tanda. Kamera sebagai alat rekam, bukan hanya berfungsi sebagai penghadir subyek namun juga Sebagai alat/mesin waktu yang mampu menghadirkan sebuah kejadian secara mundur. Apa yang terekam atau dibekukan oleh kamera merupakan sebuah kejadian yang nyata, namun hadir dalam kebekuan waktu sepersekian detik. Foto sebagai tanda (sign), tentunya memiliki makna yang tersirat baik denotatif maupun konotatif.

\section{METODE PENELITIAN}

\subsection{Incidental Documentary}

Proses penciptaan dari City of Madness berupa 'incidental documentary' atau dokumenter secara tiba-tiba yaitu fotografer mendokumentasikan foto-foto ODMK secara tiba-tiba atau tidak terencana. Meski beberapa ODMK memiliki teritori tertentu, kebanyakan dari mereka selalu berpindah tempat, sehingga sulit untuk menemukan keberadaan mereka secara pasti. Oleh karena itu, fotografer dalam memotret selalu siaga dengan kamera kamanapun fotografer pergi, dan apabila secara tidak sengaja bertemu dengan ODMK dapat langsung dipotret. Kelebihan dari metode ini adalah dapat berkarya kapanpun dan dimanapun selama obyek (ODMK) ditemui. Hasil fotopun natural dan spontan karena fotografer dituntut untuk siap memotret setiap menemukan ODMK. 


\subsection{Metode EDFAT}

Metode EDFAT (Entire, Detail, Frame, Angle, Time) yang diperkenalkan oleh "Walter Cronkite School of Journalism and Telecommunication Arizona State University", merupakan konsep pengembangan fotografi pribadi. EDFAT adalah suatu metode pemotretan untuk melatih optis melihat sesuatu dengan detil yang tajam. EDFAT merupakan suatu pembiasaan dalam fotografi spontan, maka setidaknya membantu proses percepatan pengambilan keputusan terhadap suatu event atau kondisi visual bercerita dan bernilai berita dengan cepat dan lugas. Tahapan-tahapan yang dilakukan pada setiap unsur dari metode itu adalah suatu proses dalam mengincar suatu bentuk visual atas peristiwa bernilai berita. Unsur pertama dalam metode tersebut adalah:

a. Entire (E); Dikenal juga sebagai 'established shot', suatu keseluruhan pemotretan yang dilakukan begitu melihat suatu peristiwa atau bentuk penugasan lain. Untuk mengincar atau mengintai bagian-bagian untuk dipilih sebagai obyek.

b. Detail (D); Suatu pilihan atas bagian tertentu dari keseluruhan pandangan terdahulu (entire). Tahap ini adalah suatu pilihan pengambilan keputusan atas sesuatu yang dinilai paling tepat sebagai 'point of interest'.

c. Frame (F); Suatu tahapan dimana kita mulai membingkai suatu detil yang telah dipilih. Fase ini mengantar seorang calon foto jurnalis mengenal arti suatu komposisi, pola, tekstur dan bentuk subyek pemotretan dengan akurat. Rasa artistik semakin penting dalam tahap ini.

d. Angle (A); tahap dimana sudut pandang menjadi dominan pada fase sebagai pilihan untuk posisi dalam pengambilan gambar. Apakah itu dengan memilih sudut pengambilan dari ketinggian, kerendahan, level mata, kidal, kanan dan cara lain dalam melihat sudut pandang. Pada fase ini seorang foto jurnalis menjadi penting untuk mengkonsepsikan visual apa yang diinginkannya.

e. Time (T); tahapan penentuan penyiaran dengan kombinasi yang tepa antara diafragma dan kecepatan (shutter speed) atas ke empat tingkatan metode yang telah disebutkan di atas. Pengetahuan teknis atas keinginan pembekuan gerak atau memilih ketajaman ruang adalah satu prasyarat dasar yang sangat diperlukan.

\section{HASIL DAN PEMBAHASAN}

\subsection{Hasil Penciptaan/Pemotretan}

Dalam rangkaian karya fotografi City of Madness, fotografer memotret orang gila yang ditemui di jalan-jalan kota Semarang - Yogyakarta secara tidak terduga. Foto orang gila atau lebih tepatnya ikon orang gila dihadirkan kembali dalam sebuah frame foto jurnalistik potraiture. Foto tersebut secara tersirat merekam secara detail ciri-ciri visual yang ada dalam diri mereka 

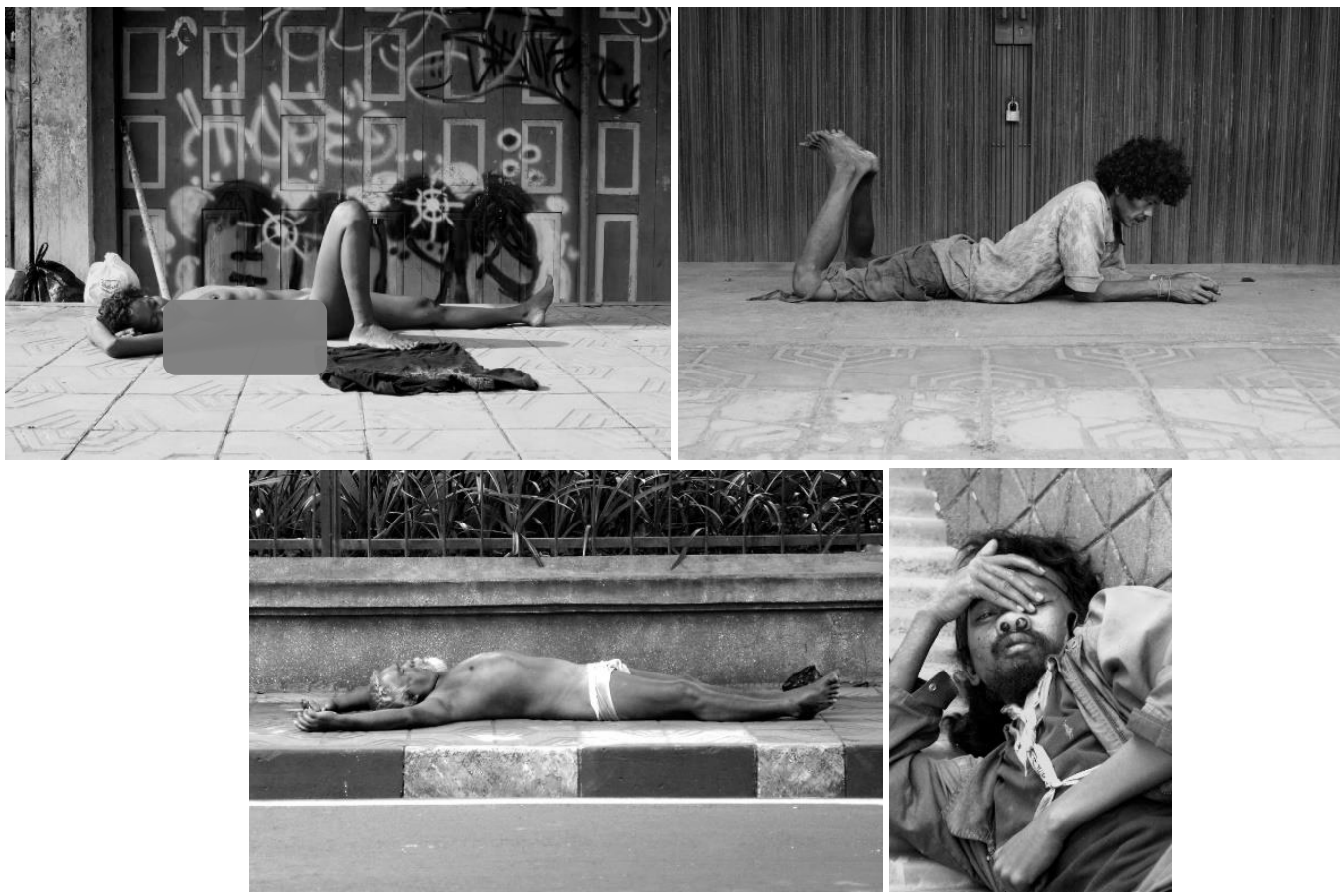

Gambar 1. Foto OMDK yang dijumpai di pinggir jalan Kota Yogyakarta.

[Sumber: Daniar Wikan, 2014-2015]

Fenomena orang gila jalanan dipotret untuk dapat direpresentasikan lewat medium fotografi, representasi ikonik tersebut memunculkan fakta bahwa mereka (orang gila) sangat mudah ditemukan dijalan-jalan kota karena jumlahnya yg banyak. Lewat fotografi kita dapat melihat secara detail mengenai perwujudan orang gila tersebut. Melalui waktu bekunya (frezzing timing), fotografi memberi kesempatan bagi kita (subyek penonton) untuk dapat mengamati lebih dalam ciriciri secara fisikal, berbeda dengan medium video yang justru memberi keleluasaan dalam mengamati garis durasi waktu (timeline). Foto tidak memiliki timeline, namun foto mengabadikan sepersekian detik kejadian dari obyek yang difoto. Di sini kamera memiliki fungsi sebagai mesin waktu, yaitu menghadirkan ulang obyek dari masa lampau.

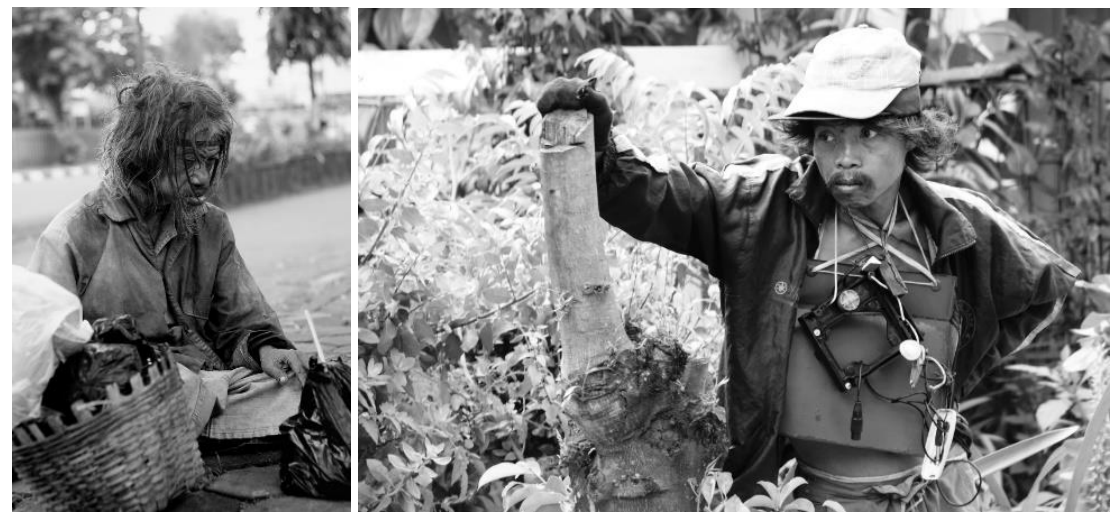

Gambar 2. Foto OMDK yang dijumpai di pinggir jalan Kabupaten Magelang.

[Sumber: Daniar Wikan, 2014-2015] 

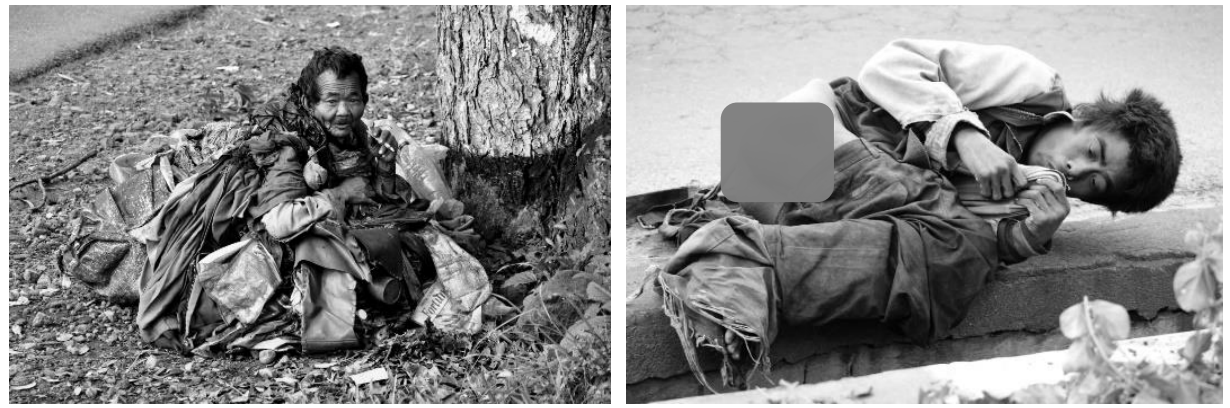

Gambar 3. Foto OMDK yang dijumpai di pinggir jalan Kabupaten Ambarawa.

[Sumber: Daniar Wikan, 2014-2015]

Melalui fotografi kita dapat mengamati ciri-ciri fisikal (ikonik) dari para ODMK yang terlantar di jalanan seperti rambut gimbal, kulit legam/kotor, seringkali terlihat setengah telanjang, tatapan yang kosong, sendirian/tidak bersosialisasi, dan berpakaian compang-camping. Meski demikian adapula ODMK yang memiliki ciri fisikal yang berbeda yaitu relatif lebih terawat, pakaian lengkap, memiliki banyak barang bawaan, mampu bersosialisasi secara terbatas. Ciri-ciri ini biasanya dimiliki oleh ODMK yang belum terlalu parah.
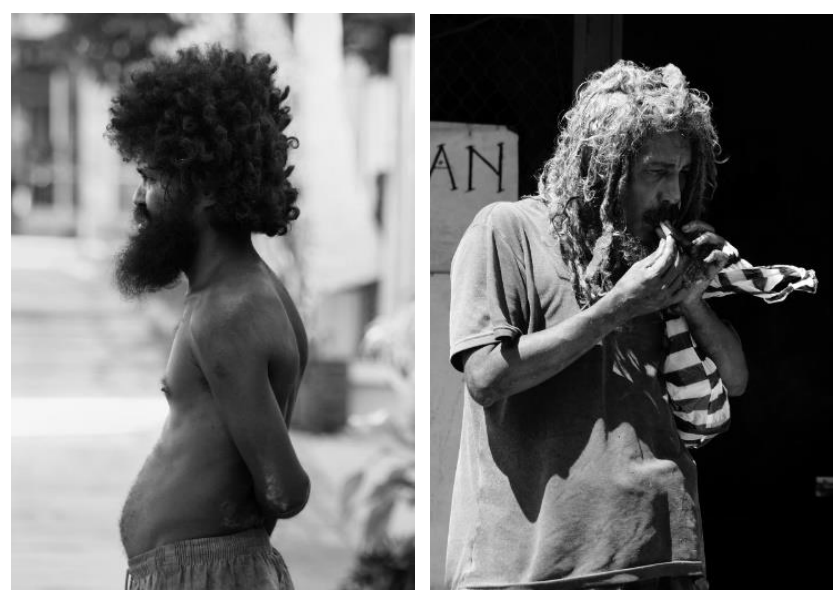

Gambar 4. Foto OMDK yang dijumpai di pinggir jalan Kota Semarang.

[Sumber: Daniar Wikan, 2015]

\subsection{ANALISIS VISUAL FOTO OMDK}

Berikut adalah analisis Ikon, Indeks, dan Simbol pada salah satu foto City of Madness yaitu foto "Kaki yang Tersembunyi"

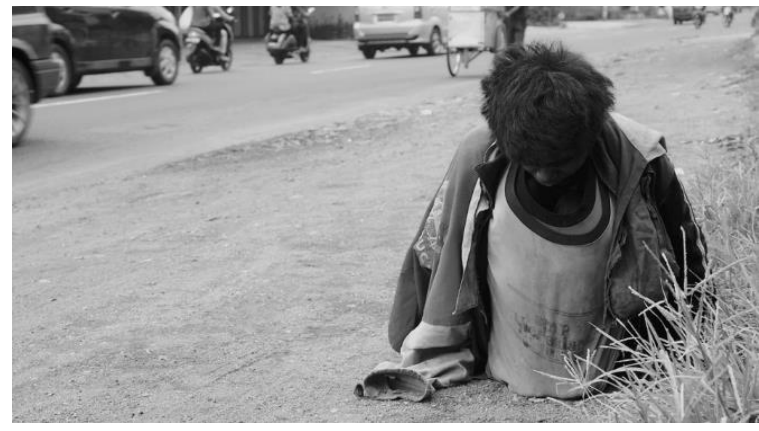

Gambar 5. foto "Kaki yang Tersembunyi", Ambarawa.

[Sumber: Daniar Wikan, 2015] 
Tabel 1. Pembahasan Ikon, Indeks dan Simbol

[Sumber: Daniar Wikan, 2015]

\begin{tabular}{|c|c|c|c|}
\hline IKON VISUAL & IKON VERBAL & INDEKS & SIMBOL \\
\hline & $\begin{array}{l}\text { Rambut pendek, } \\
\text { namun kotor, dan } \\
\text { lusuh (tidak rapi) }\end{array}$ & $\begin{array}{l}\text { Menunjukkan bahwa kondisi } \\
\text { rambut tidak terawat, tidak } \\
\text { pernah keramas dan disisir. } \\
\text { Namun kondisi tersebut } \\
\text { diasumsikan belum lama, } \\
\text { karena potongan rambut } \\
\text { relatif masih pendek, apabila } \\
\text { rambut yang tidak dirawat } \\
\text { dalam jangka waktu yg lama } \\
\text { misalkan setahun, tentunya } \\
\text { rambut tersebut sudah } \\
\text { memanjang atau gondrong } \\
\text { dan gimbal. }\end{array}$ & $\begin{array}{l}\text { Rambut merupakan sebuah simbol } \\
\text { kehormatan, pada mitos-mitos } \\
\text { jaman dahulu banyak peri cantik } \\
\text { yang digambarkan dengan rambut } \\
\text { yang indah dan panjang. Oleh } \\
\text { karena itu rambut kotor dan tidak } \\
\text { terawat pada ODMK tersebut } \\
\text { berarti bahwa ODMK telah } \\
\text { kehilangan kehormatannya sebagai } \\
\text { manusia, karena sebuah penyakit } \\
\text { kejiwaan yang dimata masyarakat } \\
\text { adalah sesuat yang memalukan } \\
\text { atau aib. }\end{array}$ \\
\hline & $\begin{array}{l}\text { Kepala yang } \\
\text { menunduk, } \\
\text { pandangan } \\
\text { melihat ke tanah } \\
\text { namun tatapan } \\
\text { dan ekspresi } \\
\text { kosong }\end{array}$ & $\begin{array}{l}\text { Diasumsikan karena ketidak } \\
\text { percayaan diri yang akut } \\
\text { sehingga malu untuk } \\
\text { menatap ke depan. Selain itu } \\
\text { kepala yang menunduk juga } \\
\text { bisa dikarenakan ketidak } \\
\text { mampuan diri untuk } \\
\text { mengangkat } \\
\begin{array}{l}\text { dikarenakan tidak } \\
\text { tenaga, semala } \\
\text { keinginan }\end{array}\end{array}$ & $\begin{array}{l}\text { Kepala merupakan simbol } \\
\text { kekuasaan atas tubuh, karena } \\
\text { kepala adalah pusat dari pikiran } \\
\text { yang menggerakkan seluruh tubuh. } \\
\text { Di kepala juga terdapat semua } \\
\text { indera yang ada pada manusia. } \\
\text { Kepala yang menunduk merupakan } \\
\text { simbol atas keputusasaan dan } \\
\text { ketidakberdayaan atas seluruh } \\
\text { tubuh, dalam kata lain ODMK tidak } \\
\text { mampu lagi mengontrol pikiran } \\
\text { serta tubuh. } \\
\text { Sedangkan ekspresi atau muka } \\
\text { adalah simbol gambaran diri atau } \\
\text { identitas. Ekspresi yang kosong dan } \\
\text { melihat kebawah tentunya } \\
\text { menyimbolkan oDMK telah } \\
\text { kehilangan identitas dan gambar } \\
\text { diri, dalam arti lain ODMK tidak lagi } \\
\text { mengenal dirinya sendiri secara } \\
\text { utuh sehingga kadang bersembunyi } \\
\text { di balik identitas lain untuk } \\
\text { menutupi identitas diri sendiri }\end{array}$ \\
\hline 2 & $\begin{array}{l}\text { Posisi tangan } \\
\text { yang lunglai dan } \\
\text { disembunyikan di } \\
\text { balik jaket, } \\
\text { sehingga telapak } \\
\text { tangan tidak } \\
\text { terlihat }\end{array}$ & $\begin{array}{l}\text { Posisi tangan tidak terlihat } \\
\text { secara jelas, karena tertutup } \\
\text { lengan jaket panjang, namun } \\
\text { terlihat posisinya lunglai, } \\
\text { tidak memegang benda dan } \\
\text { tidak sedang beraktifitas, } \\
\text { menunjukkan } \\
\text { ketidakberdayaan, dan tidak } \\
\text { adanya aktifitas fungsional } \\
\text { yang menggunakan tangan. }\end{array}$ & $\begin{array}{l}\text { Tangan merupakan sebuah alat } \\
\text { utama dalam berbagai akifitas, } \\
\text { misalnya menunjuk, memegang, } \\
\text { menggenggam, mengambil, dan } \\
\text { lain-lain. Tangan yang lunglai } \\
\text { merupakan simbol dari kelemahan } \\
\text { secara fisik. Tangan lunglai juga } \\
\text { menyiratkan arti ketidak } \\
\text { bergunaan, karena tidak mampu } \\
\text { lagi bekerja mencari nafkah dan } \\
\text { melakukan aktifitas lain. } \\
\text { Selain lunglai, tangan juga tidah } \\
\text { terlihat secara fisik (tertutup } \\
\text { lengan jaket), hal tersebut } \\
\text { menyiratkan bahwa ODMK sengaja } \\
\text { tidak mau beraktifitas karena } \\
\text { malas. Seperti pepatah "lempar } \\
\text { batu sembunyi tangan", }\end{array}$ \\
\hline
\end{tabular}




\begin{tabular}{|c|c|c|c|}
\hline IKON VISUAL & IKON VERBAL & INDEKS & SIMBOL \\
\hline & & & $\begin{array}{l}\text { menyembunyikan tangan artinya } \\
\text { tidak mau bertanggung jawab atas } \\
\text { segala hal yang pernah dia lakukan, } \\
\text { hal tersebut juga berarti ODMK } \\
\text { adalah orang yang memiliki ciri } \\
\text { tidak mau menerima kenyataan. }\end{array}$ \\
\hline & \begin{tabular}{lr}
\multicolumn{2}{l}{ Posisi kaki yang } \\
ditekuk & sejajar \\
dengan & tubuh, \\
kaki & \\
disembunyikan ke \\
dalam pakaian \\
sehingga & seakan- \\
akan & terlihat \\
seperti $\quad$ cacat/ \\
tidak punya kaki
\end{tabular} & $\begin{array}{l}\text { Ada banyak asumsi terkait } \\
\text { dengan posisi kaki. Misalnya } \\
\text { untuk menghangatkan badan, } \\
\text { melindungi diri dari panas, } \\
\text { menutupi bagian kemaluan } \\
\text { karena telanjang, dan lain- } \\
\text { lain. }\end{array}$ & $\begin{array}{l}\text { Kaki merupakan bagian tubuh yang } \\
\text { berfungsi sebagai penyangga, } \\
\text { berjalan, melompat, berlari. Kaki } \\
\text { yang disembunyikan di balik baju } \\
\text { menyimbolkan bahwa ODMK } \\
\text { merupakan manusia yang } \\
\text { kehilangan semangat hidup } \\
\text { sehingga tidak dapat melangkah } \\
\text { maju ke depan. ODMK jelas akan } \\
\text { mengalami stagnasi dalam hidup } \\
\text { dari segala sisi baik itu karir, } \\
\text { keluarga, spiritual, intelektual, dan } \\
\text { lain-lain. } \\
\text { Dalam foto ODMK tersebut } \\
\text { sebenarnya memiliki kaki hanya } \\
\text { saja disembunyikan dibalik bajunya } \\
\text { dengan cara ditekuk, hal tersebut } \\
\text { menyiratkan bahwa ODMK } \\
\text { sebenarnya memiliki kesempatan } \\
\text { untuk maju namun lebih memilih } \\
\text { diam dan stagnan dalam posisinya } \\
\text { saat ini. }\end{array}$ \\
\hline & $\begin{array}{l}\text { Kulit gelap dan } \\
\text { kotor, tubuh } \\
\text { proporsional } \\
\text { (tidak terlalu } \\
\text { kurus) }\end{array}$ & $\begin{array}{l}\text { Tubuh yang tidak terlalu } \\
\text { kurus menunjukkan bahwa } \\
\text { ODMK tersebut masih makan } \\
\text { dalam jumlah yg cukup. Kulit } \\
\text { gelap dan kotor akibat tidak } \\
\text { pernah mandi dan selalu } \\
\text { berada di luar ruang/di } \\
\text { jalanan }\end{array}$ & $\begin{array}{l}\text { Dalam isu rasial, kulit gelap sering } \\
\text { diartikan sebagai kelas } \\
\text { buruh/pekerja sedang kulit cerah } \\
\text { sering diartikan sebagai kelas } \\
\text { pemilik modal. Kulit gelap dan } \\
\text { kotor yang dimiliki ODMK tersebut } \\
\text { menyimbolkan bahwa ODMK } \\
\text { merupakan kelas sosial yang } \\
\text { terendah dalam masyarakat, atau } \\
\text { dalam arti lain adalah kelas yang } \\
\text { terabaikan. }\end{array}$ \\
\hline & $\begin{array}{l}\text { Pakaian kotor, } \\
\text { namun tidak } \\
\text { robek, celana } \\
\text { tidak terlihat, } \\
\text { karena } \\
\text { disembunyikan ke } \\
\text { dalam pakaian }\end{array}$ & \begin{tabular}{lr} 
Kotor disebabkan karena \\
lama tidak dibersihkan, \\
sedangkan kondisi pakaian \\
tidak terlihat robekan, hal \\
tersebut menujukkan bahwa \\
ODMK tersebut tidak \\
memiliki aktifitas gerak \\
berlebih, demikian juga \\
dengan celana yang \\
disembunyikan, menunjukkan \\
\multicolumn{3}{l}{ sebuah akifitas yang pasif dan } \\
tidak banyak bergerak
\end{tabular} & $\begin{array}{l}\text { Pakaian bukan hanya berfungsi } \\
\text { sebagai pelindung tubuh, namun } \\
\text { juga sebagai penanda status sosial } \\
\text { dan dinamika bahasa visual. } \\
\text { Pakaian yg kotor menyiratkan } \\
\text { bahwa ODMK tidak lagi mampu } \\
\text { melindungi tubuh. Sama halnya } \\
\text { seperti kulit gelap, pakaian kotor } \\
\text { juga menyimbolkan status sosial } \\
\text { yang paling bawah yaitu kelas } \\
\text { terabaikan. }\end{array}$ \\
\hline & $\begin{array}{lr}\text { Posisi } & \text { yang } \\
\text { berada di pinggir } \\
\text { jalan raya yg } \\
\text { ramai } \quad \text { dan } \\
\text { berseliweran } \\
\text { kendaraan } \\
\text { bermotor. } \\
\end{array}$ & $\begin{array}{l}\text { Posisi/letak di pinggir jalan } \\
\text { merupakan tanda Indeks } \\
\text { bahwa ODMK tidak memiliki } \\
\text { tempat tinggal, hidup } \\
\text { berpindah-pindah dan tidak } \\
\text { dapat bersosialisasi dengan } \\
\text { masyarakat sekitarnya. }\end{array}$ & $\begin{array}{l}\text { Posisi di pinggir jalan meyimbolkan } \\
\text { kalau ODMK hidup dengan dijauhi } \\
\text { oleh masyarakat, tidak memiliki } \\
\text { kekayaan apapun serta tidak dapat } \\
\text { hidup berdampingan dengan } \\
\text { masyarakat. }\end{array}$ \\
\hline
\end{tabular}




\section{KESIMPULAN}

Secara umum lewat karya fotografi di atas dapat disimpulkan bahwa ketika melihat orang gila maka akan timbul makna-makna berikut; kotor, lucu, menakutkan, jijik, anarkis, kasihan, bebas, bodoh, dan lain-lain tergantung bagaimana ciri-ciri fisikalnya. Makna-makna tersebut adalah makna denotatif yang ada dalam foto-foto City of Madness, sedangkan dalam tingkat konotasi foto tersebut adalah sebuah kritik sosial yang ditujukan kepada kita semua yang tidak peduli terhadap keberadaan mereka (orang gila).

Dalam sastra, kita mengenal istilah majas pars pro toto atau pengungkapan sebagian dari objek untuk menunjukkan keseluruhan objek. Penggambaran pars pro toto dari foto-foto ODMK City of Madness, merupakan makna yang bersifat simbolik atau dalam kata lain simbol dari perwakilan ikon-ikon ODMK terlantar yang ada di seluruh kota di indonesia karena secara umum memiliki ciri-ciri fisikal yang kurang lebih mirip yaitu , ciri-ciri tersebut contohnya adalah rambut gimbal, kulit legam/kotor, seringkali terlihat setengah telanjang, tatapan yang kosong, sendirian/tidak bersosialisasi, dan berpakaian compang-camping.

Dari pengamatan ikon, indeks, dan simbol maka dapat kita simpulkan bahwa makna yang dapat diambil dari foto City of Madness adalah sebagai berikut :

1. Sebuah realitas yang ada di sekitar kita mengenai keberadaan ODMK yang terabaikan dan terpinggirkan, seringkali ODMK justru menjadi sebuah pribadi yang dijauhi karena dianggap berbahaya dan merusak pemandangan.

2. Pola hidup ODMK jalanan beraneka ragam namun umumnya mereka hidup sendiri dan sulit bersosialisasi dengan masyarakat, tidak memiliki tempat tinggal dan tidak diketahui sanak saudaranya.

3. Dari ciri-ciri fisik dapat disimpulkan bahwa ODMK tidak memiliki kebutuhan dalam mengaktuallan kapasitas diri. Oleh karena itu mereka tidak bekerja, tidak berpakaian pantas, tidak melakukan aktifitas sebagaimana orang normal seperti mandi, olah raga, dan lain-lain.

4. Dalam kelas sosial ODMK berada pada titik nadir terendah, yaitu kelas terabaikan. Karena ODMK sering tidak lagi dianggap sebagai manusia, namun sebagai binatang atau bahkan sampah.

Fotografi tentunya tidak mampu mengungkapkan makna secara Indeks-sikal atau hubungan sebab akibat, karena fotografi hanya menampilkan gambar yang bersifat statis. Makna Indeks-sikal hanya dapat diamati apabila fotografi ditampilkan secara frame by frame dengan pengamatan obyek yang sama atau dalam fotografi disebut dengan continous shoot. Disinilah diperlukan peranan videografis, karena video merupakan media yang paling dapat merekam detail indeks-sikal dalam sebuah peristiwa. Seperti telah disinggung sebelumnya, video memiliki durasi atau timeline, tentunya penggambaran sebab akibat data terlihat lebih detail. Video sendiri merupakan rangkaian frame fotografis/statis yang dirangkai berurutan berdasarkan waktu (FPS/frame per second) otomatis rangkaian peristiwa Indeks-sikal dapat 
tergambar secara utuh, semakin panjang durasi semakin lengkap pula penggambaran Indeks-sikalnya.

Pengamatan fotografis, dianggap tidak mampu dalam mengambarkan gejala / peristiwa di atas, gejala tersebut hanya mampu diamati apabila ada durasi pengamatan yang disertai elemen suara/audio. Meski demikian foto dan video punya kekuatan dalam merepresentasikan obyek yan direkamnya. Foto dianggap unggul dalam menghadirkan detail ikon karena adanya resolusi yang relatif besar, tingkat ketajaman yang lebih baik, pembekuan waktu sepersekian detik juga lebih mudah apabila digunakan dalam pengamatan fisikal, sementara video unggul karena adanya durasi dan elemen suara, sehingga video lebih utuh dalam menggambarkan rangkaian peristiwa. Meski keduanya memiliki cara kerja yang berbeda, baik foto maupun video merupakan hasil rekayasa dari obyek yang ada dibalik lensa, oleh karena itu penggunaan foto dan video dalam rangkaian serial City of Madness diharapkan dapat menghadirkan makna secara lebih komplit dan mendalam.

\section{DAFTAR PUSTAKA}

Ajidarma, Seno Gumira. 2002. Kisah Mata, Fotografi antara Dua Subyek: Perbincangan tentang Ada. Yogyakarta: Galang Press.

Atmadi, T. 1985. Bunga Rampai (Catatan Pertumbuhan dan Perkembangan Sistem Pers Indonesia). Jakarta: PT. Pantja Simpati.

Darmawan, Ferry,. 2002. Teknik Fotografi-Tahap Dasar, Lab. Fotografi Fikom Unisba, (kalangan sendiri).

Beasley, W.G. 2003. Pengalaman Jepang : Sejarah Singkat Jepang. Terjmhn Masri Maris. Jakarta: Yayasan Obor Indonesia.

Efix. 2004. Para Perempuan yang Berani Telanjang. Artikel dalam harian Kompas, minggu, 26 September 2004 , hal 18

Koran tempo, edisi 10 Oktober 2016

Nugroho, R. Amien. 2006. Kamus Fotografi. Jogjakarta: ANDI.

Soedjono, Soeprapto. 2006. Pot-Pourri Fotografi. Jakarta: Trisakti. 